\title{
A MODELAGEM MOLECULAR COMO MEDIADORA DA APRENDIZAGEM DA ESTRUTURA E DA FUNÇÃO DA MOLÉCULA DE DNA
}

\author{
Elaine Ferreira Machado, UTFPR - elabio03@gmail.com \\ Awdry Feisser Miquelin, UTFPR - awdry@utfpr.edu.br \\ Marcos Brown Gonçalves, UTFPR - marcosb@utfpr.edu.br
}

Resumo: Este artigo analisa as possibilidades de uma aprendizagem significativa em uma proposta para o Ensino da Biologia, mais especificamente da molécula de DNA, com a mediação das ferramentas da modelagem molecular, bastante utilizadas na Química, mas que podem ser também transpostas para a compreensão de macromoléculas de interesse biológico. A proposta foi desenvolvida com estudantes de uma escola pública que frequentavam atividades complementares de contra turno. No decorrer das atividades desenvolvidas verificou-se uma maior compreensão da estrutura e da função do DNA quando se trabalha com a mediação das ferramentas de modelagem molecular e que, outras propostas, para o ensino podem ser desenvolvidas, aproveitando esses recursos tecnológicos disponíveis.

Palavras-chave: modelagem molecular; ensino; aprendizagem significativa; DNA

\section{MOLECULAR MODELING AS A MEDIATOR FOR THE LEARNING OF THE STRUCTURE AND FUNCTION OF THE DNA MOLECULE}

\begin{abstract}
This article analyzes the possibilities of a significant learning in a proposal for the teaching of Biology, specifically of the DNA molecule, with the mediation of molecular modeling tools, widely used in chemistry, but which can also be transposed to the understanding of macromolecules of biological interest. The proposal was developed with students of a public school that attend complementary activities of counter shift. During the development of the activities there was a greater understanding of the structure and function of DNA when working with the mediation of molecular modeling tools. Other proposals for science teaching can be developed, taking advantage of these available technological resources.
\end{abstract}

Keywords: molecular modeling, teaching, meaningful learning, DNA

\section{Introdução}

Uma das biomoléculas que mais desperta o interesse dos estudantes é o ácido desoxirribonucleico (ADN), mais conhecido como DNA. Muitos deles já ouviram falar sobre o DNA, reconhecem sua forma já que o modelo dessa molécula se tornou um ícone disseminado na nossa sociedade sendo encontrado nas mais diferentes situações, desde em manifestações artísticas, ou na mídia, ou mesmo relativo a investigações forenses e de entretenimento até, obviamente, pertencente ao universo celular. Desta forma, utilizar o DNA como ponto de partida para o estudo de biomoléculas é bastante oportuno. Entretanto, os estudantes não têm o entendimento adequado sobre estrutura-função e, principalmente as relações envolvendo condições clínicas entre o DNA e, como exemplo, o desenvolvimento do câncer (Watson, 2005). Como é perceptível que os estudantes já apresentam conhecimentos prévios sobre o DNA, mediar o ensino com ferramentas tecnológicas pode contribuir com a assimilação dos conceitos no contexto da aprendizagem significativa. 
Para Ausubel (2003, p. 72-73) "a essência do processo de aprendizagem significativa, consiste no fato de que novas ideias expressas de forma simbólica (a tarefa da aprendizagem) se relacione com aquilo que o aprendiz já sabe (a estrutura cognitiva deste numa determinada área de matérias)". Moreira e Masini (2001), embasados na teoria de Ausubel defendem que a aprendizagem significativa se caracteriza quando o estudante se torna capaz de processar e incorporar novas ideias, conceitos, informações a sua estrutura cognitiva e relacioná-lo com conhecimentos já existentes nessa estrutura.

Hoje há uma enorme carência na busca de novas ferramentas para o aprendizado significativo dos estudantes. Segundo Raupp et al. (2008, p. 15) "pode-se salientar que estas ferramentas, quando devidamente aplicadas, além de motivar a aprendizagem, colaboram com o aluno em uma sociedade cada vez mais tecnológica”.

Uma das abordagens ainda pouco empregadas é o uso da modelagem molecular no ensino. A modelagem molecular é amplamente utilizada no mundo acadêmico e em empresas farmacêuticas e de biotecnologia (Drews, 2003). Sua importância é tal que em 2013 o prêmio Nobel de Química foi contemplado aos avanços produzidos pela modelagem multiescala na ciência moderna (Skaf, 2013).

A mediação da modelagem molecular em ensino ainda é bastante insipiente havendo algumas inserções em escolas em fase de experimentação se limitando a estudos isolados em Química ou em Biologia, (Fernandez, 2006; Ramos, 2013; Santos, 2001) embora sem explorar seu caráter interdisciplinar. No entanto, a disciplina de Biologia, em diversas situações trabalha com o ensino de macromoléculas que regem a vida e, por isso, introduzir nas aulas dessa disciplina as ferramentas da modelagem molecular podem trazer contribuições para a compreensão da estrutura e da função dessas moléculas.

As ferramentas de modelagem molecular computacional permitem que o estudante crie estruturas químicas das mais simples, tais como as moléculas de $\mathrm{H}_{2}, \mathrm{~N}_{2}$, $\mathrm{H}_{2} \mathrm{O}$, passando por moléculas orgânicas complexas como fármacos e carboidratos. $\mathrm{O}$ processo de criação de moléculas utilizando os programas de modelagem molecular permite que o estudante desperte sua criatividade ao construir aleatoriamente estruturas, especialmente orgânicas, se atentando a geometria formada, a ordem de ligação e também a correta ordem de ligação.

Com o auxílio de banco de dados de biomoléculas, disponíveis na internet ou internos aos programas de modelagem molecular, é possível criar ou visualizar sequências de DNA, proteínas complexas e compreender a relação entre a química e a biologia estrutural (RCSB, 1999).

Hoje há uma série simuladores e jogos disponíveis na web, em aplicativos de celular e softwares que realizam uma simulação computacional criando um ambiente virtual para ensinar determinado conteúdo ou fenômeno (Simulações, 2017) Esta abordagem é puramente exploratória permitindo ao aluno alterar alguns parâmetros, mas o cerne do software é rígido (Moreira, 2012). Já na modelagem molecular computacional, aqui tratada, o estudante tem a possibilidade de criar estruturas moleculares, investigar suas características, com o auxílio do professor, e desta forma compreender se tal modelo molecular é factível.

Diante dessa constatação organizou-se uma sequência didática para ser trabalhada com os estudantes e, dessa forma, analisar a contribuições das ferramentas de modelagem molecular, mais especificamente através do uso do programa Discovery Studio (DS) (Discovery, 2017) e como este pode auxiliar na formação de novos conceitos pelo estudante e concretizar a aprendizagem da estrutura e função da molécula de DNA.

\section{Referencial Teórico}


A estrutura de DNA elucidada em 1953 por James Watson, Francis Crick, Maurice Wilkins e Rosalind Franklin, quando abordada em conteúdo escolar, sempre desperta o interesse dos estudantes, uma vez que, na mídia, muito se fala dessa biomolécula como possibilidade de identificação de indivíduos e seus possíveis graus de parentesco (Watson, 2005). Uma das primeiras questões levantadas pelos estudantes são os "testes de paternidade" ou o "câncer" associado a estrutura do DNA.

Embora se fale tanto sobre o DNA, verifica-se que o estudante tem um conhecimento superficial da estrutura e função dessa molécula e, por isso, apresenta dificuldades em relacioná-la adequadamente à fisiologia dos organismos. Mesmo assim, alguns subsunçores estão presentes na estrutura cognitiva dele e, por isso, no ensino, a tarefa do professor está em contribuir com a assimilação e integração de novos conceitos nessa estrutura. A construção de modelos pode ser uma forma interessante de realizar esse processo.

A própria descoberta da estrutura do DNA baseou-se na construção de modelos, por um longo período de tempo, até que em 1953, como descreve Watson (2005, p. 65): "todas as principais características do modelo de DNA se encaixaram. As duas cadeias eram mantidas coesas por fortes ligações de hidrogênio entre os pares de base adeninatimina e guanina-citosina [...] o que mais nos entusiasmou foi a complementariedade das sequências de bases ao longo das duas cadeias".

Desta forma, a descoberta da estrutura química do DNA, o pareamento das bases nitrogenadas e como a molécula comporta-se nos processos de duplicação, transcrição e tradução e, essa transposição para o ensino-aprendizagem é fundamental para que os estudantes compreendam situações tão comentadas em sala de aula como o câncer.

A construção de modelos do DNA e a ação de drogas anticancerígenas sobre ele, utilizando recursos tecnológicos como os programas de modelagem molecular, podem tornar-se uma boa opção à aprendizagem significativa da molécula e suas interações com fármacos atuais.

Segundo Ramos e Serrano (2013, p. 2) "a modelagem molecular tem como principal objetivo prever o comportamento de sistemas reais”. Para Santos (2001, p. 4) "todo tipo de estudo que envolve a aplicação de modelos teóricos utilizando os conceitos de átomo e molécula na descrição da estrutura e propriedades de interesse em química pode ser classificado como modelagem molecular".

Diante dos conceitos acima e considerando que no ensino da Biologia são estudadas várias estruturas moleculares que atuam na homeostase do organismo, a transposição dos conteúdos escolares em atividades de modelagem molecular, poderá auxiliar o estudante a compreender a estrutura e a função de macromoléculas como o DNA e a atuação de fármacos sobre ele, bem como uma proposta de aprendizagem significativa daquilo que é proposto em currículo.

Considerando que hoje os estudantes têm cada vez mais acesso aos recursos computacionais, os softwares de modelagem molecular poderiam ser mediadores no estudo de várias moléculas/estruturas porque podem "oferecer a oportunidade para os estudantes desenvolverem habilidades de pensamento mais complexas, principalmente àqueles que não possuem a habilidade viu espacial bem desenvolvida" (Ramos e Serrano, p. 98, 2015).

O software DS, segundo as proposições de Ausubel (2003) facilita a atuação pedagógica e, por isso, torna-se um material potencialmente significativo na aquisição de novos significados. Lembrando sempre que a aprendizagem significativa não é sinônimo de material significativo, mas um material potencialmente significativo contribui com esse processo na medida em que novas ideias aprendidas se relacionam com os subsunçores dos estudantes (ideias que já existiam na estrutura cognitiva do aprendiz) 
porque "o material significativo (conteúdo da matéria no contexto da aprendizagem escolar) é sempre, e apenas pode ser, apreendido em relação a uma base de conceitos e de princípios relevantes, anteriormente apreendidos por um determinado aprendiz e, também, a informações pertinentes que tornam possível o aparecimento de novos significados e melhoram a organização e a retenção dos mesmos"'(Ausubel, 2003, p. 10).

Moreira (2012, p. 13) afirma que a aprendizagem significativa "depende de subsunçores adequados, da predisposição do aluno para aprender, de materiais potencialmente significativos e da mediação do professor".

As considerações acima aproximam-se também da proposta da Educação Básica em Ciências da Natureza em que o documento orientador da Base Nacional Comum para as disciplinas de Biologia, Física e Química propõe que o "ensino das ciências será realizado a partir de diferentes estratégias e com o uso de múltiplos instrumentos didáticos, buscando sempre promover o encantamento, o desafio e a motivação de crianças, jovens e adultos para o questionamento" (BRASIL, 2015, p. 150).

Por isso, a modelagem molecular aproxima-se dessa característica investigativa, interdisciplinar e de mediação dos recursos tecnológicos na Educação Básica, bem como de um processo de ensino-aprendizagem que prioriza os conhecimentos prévios dos estudantes (subsunçores), mas, ao mesmo tempo, com atividades metodológicas criativas, instiga a curiosidade, a pesquisa e a simulação para compreender as estruturas que compõem os seres vivos, integrando novos conhecimentos.

O conceito/símbolo do DNA encontra-se presente entre os estudantes adolescentes, mas como realmente é a estrutura, quais são suas subunidades e como elas interagem entre si, tanto em células saudáveis, não saudáveis e em tratamento com quimioterápicos são ideias e conceitos que, na medida que as aulas da sequência didática ocorreram, foram assimiladas pelos estudantes, com a mediação do DS.

\section{Metodologia}

A proposta de modelagem molecular no ensino da Biologia, mais especificamente da molécula de DNA foi realizada com estudantes de quatorze a dezesseis anos $\left(9^{\circ}\right.$ ano do Ensino Fundamental II, $2^{\circ}$ e $3^{\circ}$ anos do Ensino Médio), de uma escola pública, nas atividades de contra turno desenvolvidas no projeto de Iniciação Científica.

Primeiramente os estudantes responderam a um questionário para investigar os subsunçores desses estudantes (Quadro 1). O objetivo do questionário foi a identificação dessas estruturas que poderiam ser utilizados para potencializar a aprendizagem significativa com o DS.

Foi elaborada uma sequência didática sobre o DNA e a ação dos quimioterápicos sobre essa molécula, utilizando para isso os momentos pedagógicos propostos por Delizoicov, Angotti e Pernambuco (2009), conforme Quadro 1:

Quadro 1: Sequência didática com mediação do DS no ensino-aprendizagem de macromoléculas

\begin{tabular}{|l|l|}
\hline \multicolumn{1}{|c|}{$\begin{array}{c}\text { MOMENTOS } \\
\text { PEDAGÓGICOS }\end{array}$} & \multicolumn{1}{c|}{ AÇÕES DE ENSINO-APRENDIZAGEM } \\
\hline Problematização & Como os medicamentos quimioterápicos agem nas células cancerígenas? \\
\hline $\begin{array}{l}\text { Organização do } \\
\text { conhecimento }\end{array}$ & $\begin{array}{l}\text { - Realizar, em trios, pesquisas bibliográficas sobre o tema } \\
\text { - Aula prática de extração de DNA de morangos. } \\
\text { - Registrar as principais informações sobre o DNA e a ação dos medicamentos } \\
\text { sobre essa biomolécula. } \\
\text { - Investigar os principais receptores biológicos de drogas anticancerígenas em } \\
\text { biomoléculas (proteínas/DNA, etc.) e/ou organelas } \\
\text { - Em casa e no laboratório de informática da escola utilizar o programa } \\
\text { computacional/software Discovery Studio 3.5 (DS) para confeccionar a } \\
\text { moléculas de DNA e os fármacos. }\end{array}$ \\
\hline
\end{tabular}




\begin{tabular}{|c|c|}
\hline & $\begin{array}{l}\text { - Investigar as diferentes formas de ligação de drogas que agem principalmente } \\
\text { no DNA: interação por intercalação, interação via alça (sulco) maior e alça } \\
\text { menor. } \\
\text { - Na simulação, inserir o medicamento e observar sua ação na molécula de } \\
\text { DNA. } \\
\text { - Anotar as ações desse medicamento no DNA e como ele pode agir em células } \\
\text { cancerígenas e não cancerígenas. } \\
\text { - Realizar pesquisas bibliográficas sobre o desenvolvimento que vem } \\
\text { ocorrendo de medicamentos }\end{array}$ \\
\hline $\begin{array}{ll}\text { Aplicação } \\
\text { conhecimento }\end{array}$ & $\begin{array}{l}\text { - Relatório das atividades desenvolvidas pelos estudantes, mencionando os } \\
\text { procedimentos realizados na aula e as possibilidades futuras de novos } \\
\text { medicamentos no combate ao câncer. } \\
\text { - Confecção de um modelo no software DS sobre o DNA e ação de } \\
\text { quimioterápicos. }\end{array}$ \\
\hline
\end{tabular}

Fonte: os autores.

Concluída a sequência didática, os estudantes responderam outro questionário (Apêndice 2) para que a análise proposta no artigo pudesse ser realizada pelos autores. Tanto o questionário pré-teste como o pós-teste contaram com questões abertas para auxiliar na compreensão dos resultados obtidos tanto de forma quantitativa como qualitativa.

\section{Resultados e Discussão: A Mediação do Programa Discovery Studio (DS)}

O software Discovery Studio (DS) Visualiser é um recurso computacional distribuído pela empresa Biovia, desenvolvedora de softwares científicos (Discovery, 2017). Utilizamos uma versão livre, não comercial, que contém apenas as ferramentas de criação e visualização molecular.

Ao realizar uma consulta dos softwares livres de modelagem molecular disponíveis no mercado verificamos que há dezenas destes com as mais variadas capacidades e recursos. O programa DS foi escolhido devido a sua interface bastante amigável e atrativa com funções simples que facilitam a interação do estudante da escola básica.

Por ser um software desenvolvido por uma das grandes empresas de simulação científica do mundo, este é bastante estável, com recursos gráficos muito atraentes o qual facilita a interatividade com o estudante. Em especial, o DS apresenta recursos que vão além da maioria dos demais softwares de modelagem molecular, permitindo a visualização criação e edição das estruturas, indicativos de hibridização das ligações além de recursos como um banco de dados interno com centenas de moléculas orgânicas e inorgânicas. Em especial para o trabalho aqui realizado, há ferramentas para a construção de ácidos nucleicos e proteínas partindo dos nucleotídeos e aminoácidos.

O programa DS na versão 3.5 foi instalado nos laboratórios de informática de uma escola pública da Rede Estadual do Paraná utilizando computadores Linux Educacional versão 4.0. Os estudantes primeiramente aprenderam as ferramentas básicas envolvidas na construção de pequenas moléculas orgânicas e inorgânicas, acrescentar elementos químicos, trabalhar com ligações covalentes e corrigir de forma adequada a ordem de ligação das estruturas criadas.

Após esta prévia capacitação dos estudantes, introduzimos o estudo dos nucleotídeos e da construção da dupla hélice do DNA conforme apresentado na Figura 1: 


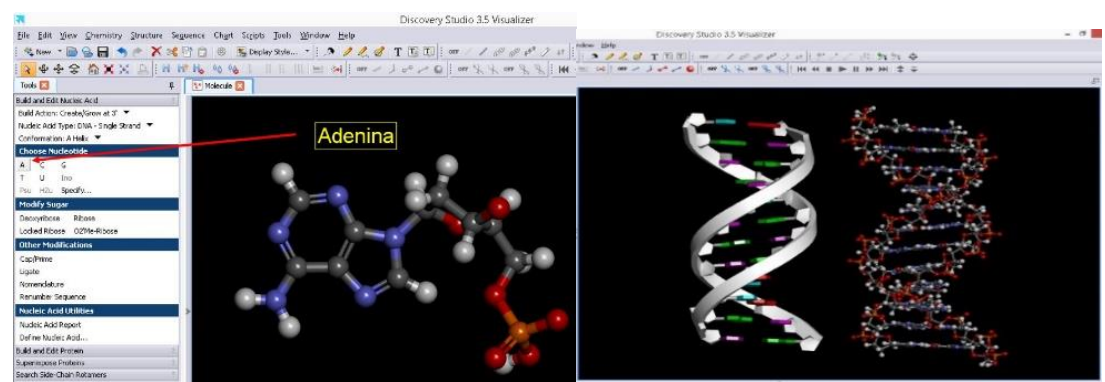

Figura 1: Representação esquemática do nucleotídeo com a base nitrogenada adenina (direita); dupla fita do DNA visto no formato da estrutura secundária e na representação atômica criada no programa DS (esquerda). Fonte: os autores.

Os estudantes representaram, esquematicamente as moléculas no DS e, com as ferramentas disponíveis, observaram a estrutura do DNA em diferentes configurações, como apresentado na Figura 1. Salientamos que é possível criar com a modelagem molecular simulações realistas da dinâmica das estruturas estudadas embora neste primeiro trabalho a "movimentação" das estruturas foi realizada apenas via intervenção do professor ou dos estudantes.

Com o desenvolvimento da sequência didática mediada pelo DS foi possível chegar aos resultados quali-quantitativos descritos, analisados e discutidos abaixo.

A primeira questão do questionário perguntava se os estudantes já haviam ouvido falar sobre a molécula de DNA. Como resposta, $100 \%$ dos estudantes afirmaram que sim. As principais fontes onde esses estudantes ouviram falar da molécula de DNA estão demonstradas no Gráfico 1, abaixo:

Gráfico 1: fontes de informação sobre o DNA

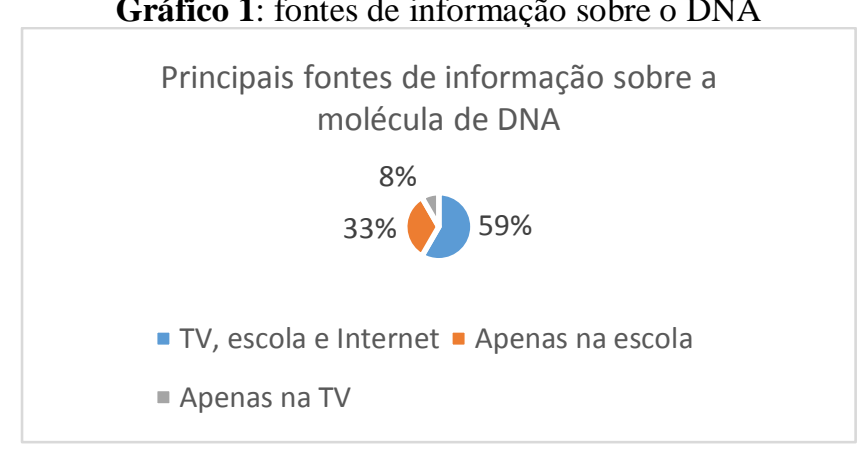

Fonte: questionário aplicado para os estudantes.

Os estudantes que afirmaram já ter ouvido falar sobre a molécula de DNA, as respostas que permitiram compreender como eles entendem essa estrutura podem ser destacadas em repostas como: "É ele que nos define, tipo assim ele é nossa genética, temos DNA humano, somos humanos"; "alguma coisa a ver com a genética algo que está no sangue”.

Verifica-se, nas repostas dos estudantes, que muitos deles trazem os conhecimentos veiculados principalmente pela mídia quando relatam o que é o DNA. Desta forma, para compreender melhor esses subsunçores solicitamos que esses estudantes desenhassem como é, estruturalmente, o DNA. Ausubel (2003) considera que eles são fundamentais para a aquisição de novos significados pelo estudante. De 15 estudantes apenas cinco estudantes foram capazes de representá-lo, como demonstra o Gráfico 2: 
Gráfico 2: Representação da estrutura do DNA.

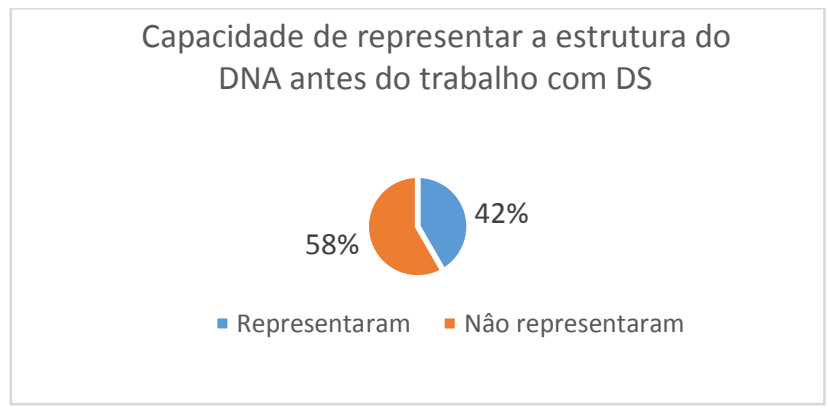

Fonte: questionário aplicado aos estudantes.

Nessa questão, mesmo a representação tendo sido realizada com as duas fitas que compõem a molécula, apenas um estudante foi capaz de representa-la com as bases nitrogenadas e com as ligações de hidrogênio que realizam a ligação entre as fitas para formar a dupla-hélice.

Concluída a sequência, ao desenhar novamente a molécula de DNA, verificou-se uma apropriação das estruturas da molécula após o trabalho com o DS, pela maioria dos estudantes da pesquisa, inclusive com os detalhes das ligações de hidrogênio e bases nitrogenadas. Constatou-se que $77 \%$ dos estudantes conforme demonstra o Gráfico 3, fizeram a assimilação de como é a estrutura do DNA. Isso demonstra que um material potencialmente significativo (o DS) potencializa a aprendizagem significativa, com a aquisição de novos conceitos no processo de ensino-aprendizagem.

Os $23 \%$ dos estudantes que não representaram, esquematicamente a molécula, deixaram a questão em branco, mas foram estudantes que, no simulador, realizaram a representação. Mesmo assim, ocorreu um aumento do número de estudantes que conseguiram representar a molécula (20\%). Considerando o tempo destinado a essa construção (em média duas horas) no DS, o aumento do número de horas e atividades com a simulação computacional poderiam trazer resultados melhores.

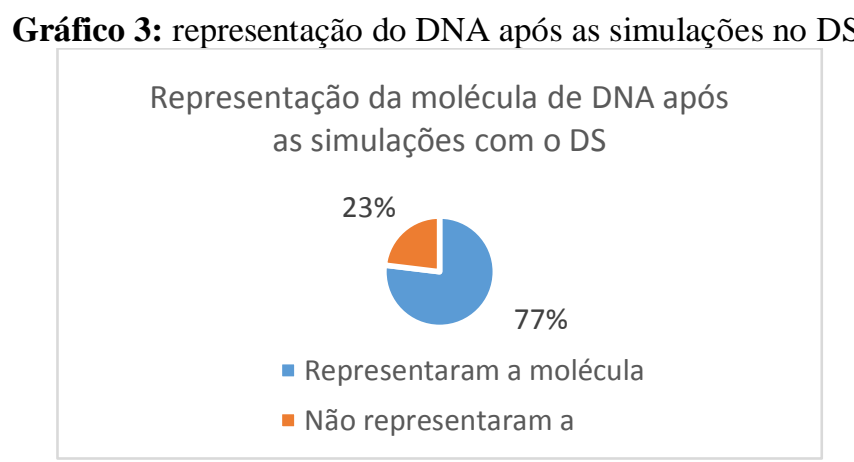

Fonte: o questionário aplicado aos estudantes.

Sobre as contribuições do DS para a representação do DNA e entendimento dessa molécula biológica, os estudantes afirmaram que: "Aprendemos a estrutura do DNA, com representação em $3 D$ das imagens, assim criamos moléculas, DNA e proteínas"; "Poder observar o DNA como realmente ou perto disso. O DS ajudou muito a saber mais sobre o DNA".

Com as respostas acima, verifica-se que o DS traz evidências de aprendizagem significativa, caracterizando-se como uma tecnologia de mediação, fazendo pontes cognitivas entre o novo conhecimento e aquilo que já estava presente na estrutura cognitiva do aprendiz (Ausubel, 2003), pois permite que estruturas visualizadas apenas 
em livros didáticos ou imagens bidimensionais possam ser construídas e observadas em simulações computacionais.

A mesma sequência didática contribui com a apropriação das relações entre DNA e câncer, bem como abriu novas possibilidades de relacionar outras macromoléculas a uma doença que, cada vez mais acomete a população e preocupa os jovens estudantes: "O câncer ele modifica as células e o DNA, fazendo com que o DNA faça replicações acima do normal"; "O DNA fica no núcleo da célula, quando a célula é afetada o DNA também é afetado. Ele pode se replicar assim nascerão novas células cancerígenas".

Na simulação realizada em sala de aula, com a mediação do DS, uma molécula quimioterápica, a cisplatina, foi adicionada ao DNA construído pelos estudantes (Figura 2). Eles observaram a ação da molécula deformando a estrutura molecular do DNA e, após as atividades da sequência didática, eles concluíram que os medicamentos quimioterápicos são/agem: "Medicamento quimioterápico é um medicamento usado na quimioterapia como a cisplatina. Eles agem neutralizando o DNA para que ele não possa se replicar e assim espalhar mais 'células doentes.".

Assim, conforme o estudo proposto nesse artigo, os estudantes responderam como as simulações realizadas no Discovery Studio (DS) contribuíram para o seu entendimento e a formação de novos significados sobre a estrutura do DNA e a ação de uns determinados medicamentos quimioterápicos conforme apresentado na Figura 2:
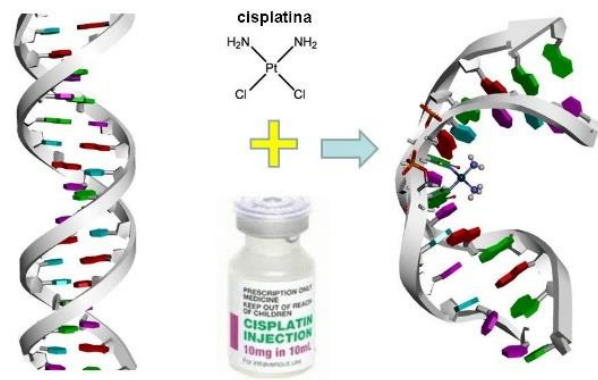

Figura 2: Descrição esquemática da interação da droga cisplatina com o DNA apresentada aos estudantes. O composto sabidamente deforma localmente a estrutura secundária do DNA. Fonte: Silverman, 2002 e adaptação dos autores.

Sobre essa interação, medicamento e DNA, os estudantes afirmaram que: "Montando o DNA e depois colocando o quimioterápico no meio dele dá para vermos os efeitos que causam. O DNA ficou torto"; "Houve maior visualização do formato do DNA, como ele fica danificado e como o medicamento precisa agir".

Como tratou-se de uma pesquisa quali-quantitativa, algumas questões poderiam não ter contemplado o estudo e, por isso, na última questão do questionário pós-teste foi aberto um espaço para que os estudantes escrevessem sobre o aprendizado desencadeado com as simulações do DS. As respostas foram: "No DS as simulações são muito próximas da realidade"; "Pois com o DS podemos ver a simulação de como isso ocorre" (referindo-se à ação do medicamento).

Com os dados obtidos constatou-se um maior envolvimento dos estudantes nas aulas com a mediação do DS. Como trata-se de estudantes jovens, a habilidade que possuem com as tecnologias de softwares e aplicativos contribui para a exploração do assunto trabalhado, para a curiosidade e para a confecção das moléculas.

O DS, segundo Ausubel (2003, p. 11) caracteriza-se como um organizador avançado pois facilita a aprendizagem significativa de tópicos ou conteúdos a medida que "é um mecanismo pedagógico que ajuda a implementar estes princípios, estabelecendo 
uma ligação entre aquilo que o aprendiz já sabe e aquilo que precisa de saber, caso necessite de apreender novos materiais de forma mais ativa".

Dessa forma, a mediação do DS, nas aulas de Biologia, contribui e traz indícios de uma aprendizagem significativa, que valoriza os subsunçores dos estudantes e, a partir deles, transforma-os em situações para que novos conhecimentos sejam apropriados conforme eles realizam as simulações computacionais, interagem com elas, trocam informações e realizam reflexões com o professor da disciplina.

\section{Considerações Finais}

Ensinar Ciências, na escola básica, requer metodologias apropriadas e que instiguem a capacidade criativa e inventiva dos estudantes em compreender os conteúdos escolares. No entanto, quando se trata de estruturas moleculares tem se observado dificuldades por esses estudantes, sendo estas sanadas com a construção de maquetes e modelos didáticos que os auxiliem. Como o tempo e o espaço escolar muitas vezes não permitem tais construções, uma das alternativas está nas simulações computacionais, considerando a habilidade dos estudantes com as Tecnologias da Informação e Comunicação (TIC) e sua presença no cotidiano dos estudantes.

O DS caracteriza-se justamente como uma opção, pois permite a construção de moléculas tanto no Ensino Fundamental quanto no Ensino Médio com os estudantes. Segundo Rodrigues (2001, p. 44) "um programa de modelagem molecular permite a representação, visualização e determinação de parâmetros geométricos de uma molécula isolada, além de realizar estudos em macromoléculas e complexos droga-receptor" e, por isso, contribui com o ensino-aprendizagem na escola básica, tornando-se um material potencialmente significativo à aprendizagem.

Da mesma forma que a modelagem molecular tem se tornado uma ferramenta importante na confecção de novos fármacos em laboratórios de pesquisa, essas ferramentas podem ser introduzidas, com o devido planejamento, nas escolas para o Ensino de Ciências, potencializando a capacidade de interação dos estudantes com a tecnologia da modelagem e permitindo que essa mesma tecnologia contribua com a construção, observação e compreensão de moléculas que são colocadas como conteúdos nos currículos escolares em uma aprendizagem significativa, com materiais potencialmente significativos que contribuam com a apropriação de conhecimentos.

Para Ramos e Serrano (2013) os softwares de modelagem molecular poderiam ser transpostos para atividades com diversas moléculas estudadas na escola e, como as pesquisas na escola básica ainda são escassas, novas propostas de atividades com essas ferramentas podem contribuir com a inserção crítica e reflexiva dessa ferramenta pelos professores, no ensino.

Para Delizoicov et. al (2009) "o professor de Ciências Naturais encontra-se em posição privilegiada em relação a outros profissionais da escola, à medida que, por sua formação básica e pela quantidade de material da área disponível na Internet ou sob outras formas eletrônicas, ele tem mais facilidade para usar os recursos informacionais".

Por isso, pensar em práticas metodológicas que insiram os recursos da modelagem molecular no planejamento das aulas, trará contribuições para uma aprendizagem significativa e mais problematizadora dos conhecimentos científicos.

\section{Referências}

AUSUBEL, D. P. Aquisição e Retenção de Conhecimentos: uma perspectiva cognitivista. Rio de Janeiro: Plátano Editora, 2003. 
Brasil. (2015). Programa Ensino Médio Inovador: Documento Orientador. Acesso em $26 \quad$ fev. 2017.2 Disponível http://www.gestaoescolar.diaadia.pr.gov.br/arquivos/File/sem_pedagogica/fev_2016/an exo5_dge_3dia_sp2016.pdf. Acesso em: 30. Abr. 2017.

Dassault Systèmes BIOVIA. Discovery Studio Modeling Visualizer Environment, Release 2017, San Diego: Dassault Systèmes.

DELIZOICOV, D; ANGOTTI, J. A; PERnAmbuCO, M. M. Ensino de Ciências: fundamentos e métodos. São Paulo: Cortez, 2009.

DREWS, J. Strategic trends in the drug industry. Drug Discovery Today, v. 8, n. 9, p. 411-420, 2003.

MOREIRA, M.A.; MASINI, E.A.F.S Aprendizagem significativa: a teoria de David Ausubel. 2 ed. São Paulo: Centauro, 2001.

MOREIRA, M. A. Teorias da Aprendizagem. 2 ed. ampl. São Paulo: EPU, 2011.

MOREIRA, M. A. O que é afinal aprendizagem significativa?. Qurriculum. Espanha: La Laguna, 2012. Disponível em: http://moreira.if.ufrgs.br/oqueeafinal.pdf. Acesso em 30. Abr. 2017.

MOREIRA, M. A. Modelos científicos, modelos mentais, modelagem computacional e modelagem matemática: aspectos epistemológicos e implicações para o ensino. Revista Brasileira de Ensino de Ciência e Tecnologia, v 7, n 2, p 1-20, 2012.

RAMOS, A. F.; SERRANO, A. Modelagem Molecular no Ensino de Ciências: uma revisão de literatura no período de 2001-2011 acerca de sua aplicabilidade em atividades de ensino. Actia Scientiae, v. 15, n. 2, p. 363-382, 2013.

RAMOS, A. F,; SERRANO, A. Uma proposta para o ensino de estereoquímica cis/trans a partir de uma unidade de ensino potencialmente significativa (UEPS) e do uso da modelagem molecular. Experiências em Ensino de Ciências, v. 10, n. 3, p. 94- 106, 2015 .

RAUPP, D; SERRANO, A; MARTINS, T. L. C. A. A evolução da química computacional e sua contribuição para a educação em Química. Revista Liberato, v. 9, n. 12, p. 13-22, 2008.

RODRIGUES, C. R. Processos modernos no desenvolvimento de fármacos: modelagem molecular. Cadernos Temáticos de Química Nova na Escola, n. 3, maio, 2001.

WATSON, J. D. DNA: o segredo da vida. Companhia das Letras. Rio de Janeiro, 2005.

RCSB PROTEIN DATA BANK. Banco de dados de proteínas: no ar desde 1999. Disponível em <http://www.rcsb.org>. Acesso em 20 ser. 2017.

SILVERMAN, A.P., BU, W., COHEN, S.M., LIPPARD, S.J. 2.4-A Crystal Structure of the Asymmetric Platinum Complex $\{\mathrm{Pt}($ ammine)(cyclohexylamine) $\} 2+$ Bound to a Dodecamer DNA Duplex, J.Biol.Chem., v. 277, p. 49743-49749, 2002.

SIMULAÇÕES INTERATIVAS EM CIÊNCIAS E MATEMÁTICA. Disponível em:<https://phet.colorado.edu/pt_BR>. Acesso em 20 set. 20017.

SKAF, M. S. O Prêmio Nobel de Química 2013. Química Nova na Escola, v. 35, n. 4, p. 243-246, 2013. 